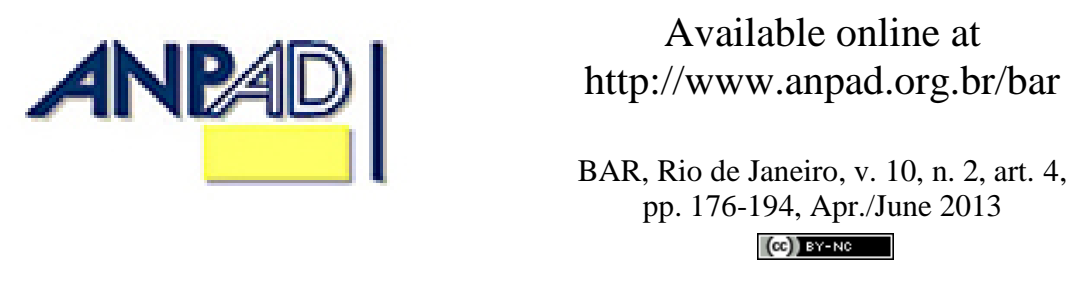

\title{
Organizational Sacralization and Discursive Use of Corporate Mission Statements
}

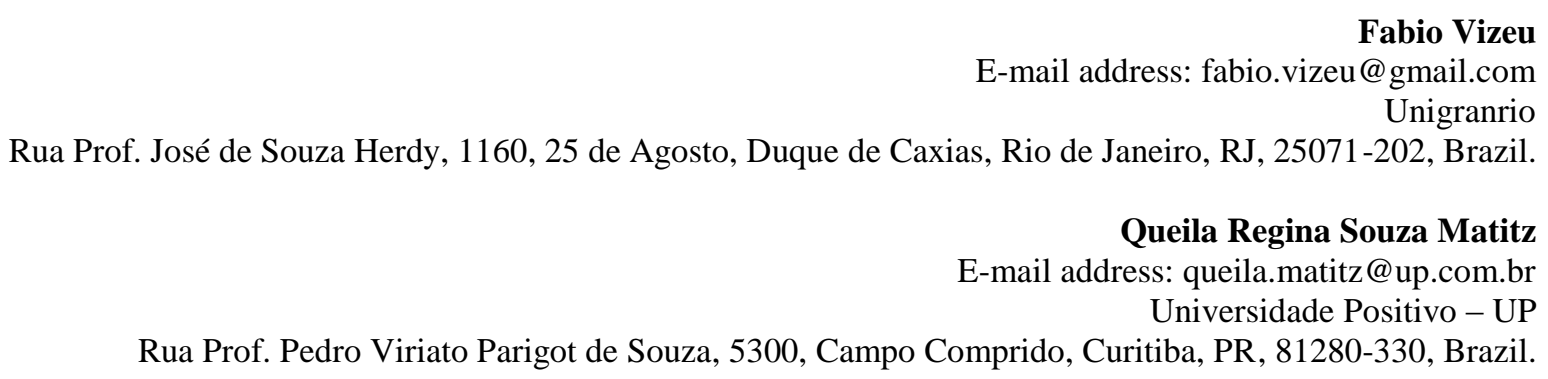

Received 21 April 2012; received in revised form 31 August 2012; accepted 11 October 2012; published online $1^{\text {st }}$ April 2013. 


\begin{abstract}
The religious origin of organizational behavior is not easy to recognize, nor are the implications of the Christian heritage of concepts and ideas as applied to organizations. This paper seeks to remedy this by investigating the theological roots of the mission concept. Our central argument is that corporate mission statements are sometimes used as manipulative communicative tools which seek organizational legitimacy through the rhetorical inclusion of secularized Christian values. We find in Koselleck's (1985) Conceptual History theoretical arguments by which to evaluate the bridge between theological and corporate concepts of mission. Then, we discuss mission as a theological concept, showing how it developed in modern societies and how its discursive use in business can be evaluated. With an analysis based on Habermas' (1985) work, we conclude that, as a communicative tool, a corporate mission statement helps organizations manipulate meanings about their purposes and legitimacy in Christianity-based societies. This process reveals how the mission concept contributes to increase organizational sacralization and represents a powerful tool for improving a corporation's social image and as a consequence may induce social consent.
\end{abstract}

Key words: corporate mission statement; organizational sacralization; corporate image; discursive use of corporate mission. 


\section{Introduction}

Since Weber came to regard secularization as the most important process in the historical defining of modernity, contemporary social practices have mistakenly been seen by many sociologists as expressions of the declining levels of religiosity (Davie, 2010). In this sense, for-profit organizations are acknowledged to be among the major secular institutions in modern societies and are mainly oriented towards rational values (Friedland \& Alford, 1991). In spite of this, Weber also identified in the Christian religious expansion in the West an explanation for the dissemination of the spirit of our current economic conduct, specifically in the ascetic protestant concept of vocation, the religious idea which he used to endow work with divine importance (Weber, 2001).

Weber's insight leads us to wonder how secular Western contemporary culture came to be built upon a Christian tradition. Because it was, religion had a considerable effect on modernization, above all in creating the conditions for new attitudes about work and capital accumulation, new social roles and increasing social mobility, growing individualism and the emergence of cities and nation-states (Bruce, 2010). Thus, although the corporate world is characterized by secularization, it is also true that the principles of religious thought can often be found in for-profit organizations (Ashforth \& Vaidyanath, 2002), in the sense that, through the influence of the European religious tradition in the Americas resulting from centuries of Christian colonization, these Christian values and ideas are deeply embedded in organizational practices (Benefiel, 2003; Porterfield \& Corrigan, 2010). According to this analytical framework, the theological roots of organizational concepts - like mission, for example - are not always self-evident, but they may be inferred through the interpretation of social, economic, political and cultural roots. And, considering strong economic and political influence on missionary initiatives in the Americas, especially in Brazil and other Latin American countries, we may infer a religious influence over the interpretation of concepts, especially those related to capitalism.

In some sense, these values and ideas must be considered the fuel of modern organizational behaviour (Demerath, Hall, Schmitt, \& Williams, 1998). Unfortunately, this religious influence on organizational behaviour is far from easy to recognize, as are the implications of this Christian tradition for the concepts and ideas of organizations (Benefiel, 2003). This is a very important consideration for a critical view of organizational practices (Ashforth \& Vaidyanath, 2002). This paper seeks to remedy this difficulty by exploring the theological roots of the concept of mission so as to shed light on the use which organizations make of the term through the practice of elaborate corporate mission statements. Largely used in strategic management, the corporate mission statement is an important tool of managerial practice (Ireland \& Hitt, 1992), for it gives organizational activities a sense of direction, helps to build and communicate a desirable image of a corporation and improves employees' motivation and performance (Bart, 1997; Williams, 2008). Moreover, following the current demand for corporations to have a positive social image, the process of corporate image building using corporate mission statements seems to be mainly diverted to discursive purposes. This is because it can be draped over the potentially prejudicial purposes of capitalistic enterprise by suggesting that corporations have a moral purpose, which society should accept almost as a divine project (Harrison, Ashforth, \& Corley, 2009).

By including a critical view with organizational analysis (Forester, 1983), we find this discursive use of corporate mission to be an interesting illustration of communicative distortion. Understood as a discursive mechanism for manipulating meaning and providing social consent, we submit that a corporate mission can be used to stress the theological meanings in which the term mission is embedded. In considering corporate mission statements as a discursive category, we understand discourse as: (a) a culturally situated communicative practice; (b) represented by a set of texts; and (c) pervaded by relationships of power and political interaction which are expressed through language and meaning (Phillips \& Hardy, 2002). 
To endorse our argument about the theological heritage of the corporate mission concept, we use Koselleck's $(1985,2002)$ insight into the centrality of the historical analysis of concepts to illuminate modern values and understandings. According to Koselleck, the analysis of modern concepts implies a consideration of their diachronic dimension, which can still reveal some traces of the original understanding, albeit changed by time. Koselleck's view also shows that concepts are used by a social group as linguistic resources for theoretical adjustment, obtained by a set of shared meanings which have been maintained, incorporated or modified over the course of their historical journey (Koselleck, 1985, 2002). Thus, with this perspective we build a bridge between the original concept of mission and the modern corporate conceptualization of it; such that, although the two mean different things, a kind of maintenance of the original meaning can be identified - built in a religious tradition - in the more recent conceptual development of its present-day corporate usage.

Beyond the introduction, this paper has six parts. The first presents the business conception of mission and its use as a discursive tool. The second part presents the Habermasian notion of communicative distortion, and shows how this critical view can be applied to organizational communication and, specifically, to corporate mission statements. The third part discusses Koselleck's Conceptual History and ways to understand religious and corporate concepts from this perspective. In the fourth part, a brief overview of the Americas colonial history is presented, to show how European Christian thought influenced the culture of contemporary Western societies. Also, this part presents the etymology of the concept of mission and some aspects of its historical trajectory in theological thought, highlighting the fact that even there this concept assumes a secular dimension. In the fifth part three theological principles identified in the discursive structure of corporate mission statements are illustrated which show the implications of the heritage of theological meanings in business. In the conclusion, we stress the idea that, in many cases, corporations adopt the mission concept because it represents a powerful tool for improving a corporation's social image, producing consent and trust despite the selfish corporate purpose of maximising profits.

\section{The Corporate Concept of Mission}

It is unclear when and by whom the concept of mission was introduced to the corporate world. In the academic literature, there are references to the term mission early in the first half of the twentieth century, but concern with conceptual definitions of it when used as a managerial tool arises unmistakably with the adoption of the phrase mission statement. This concern is apparent in the development of strategic planning practice, which had its greatest impetus in the 1970s (Mintzberg, 1994). According to this literature, the mission statement is a managerial tool in the sense that it "can help focus the organization on what really matters" (Ireland \& Hitt, 1992, p. 34), thus showing the organizational focus to different publics.

The literature on mission statements highlights different and sometimes conflicting aspects of the use of the concept (Bartkus, Glassman, \& McAfee, 2000). Nonetheless, Williams (2008) finds a consensus regarding the need to define the concept of corporate mission and to make recommendations for its content. In this sense, we can identify, associated with the function of providing focus and direction, a managerial concern with encouraging performance in line with the statement, insofar as the mission statement serves as a source of inspiration (Bart, 1997). This lets us infer the intentional use of the corporate mission statement as a powerful communicative tool (Williams, 2008).

As a communicative tool, the mission statement provides an organization with some practical benefits (Bartkus et al., 2000). In addition to serving as a focus for strategic and managerial guidance, the clear definition of organizational purpose expressed by the mission statement gives an organization an identity (Leuthesser \& Kohli, 1997). Following the concept of organizational identity as a factor of both the organization's distinctiveness and the employees' identification with their workplace (Alvesson \& Willmott, 2002), the mission statement supports this identity in that, on the one hand, it 
reveals the distinction or differentiation of the business from its competitors and, on the other, it reconciles its various stakeholders. Yet the organizational distinctiveness expressed through the mission statement helps to build multiple types of relationship between the corporation and its internal and external audience. Accordingly, the mission statement as a communicative tool expresses a selfimage constructed by managers which influences the degree to which different stakeholders are involved with the organization. This intended commitment is expressed in a variety of ways, such as consumers' desire to consume the products of the company, shareholders' support for top executives' decisions, employees' motivations to perform their tasks, or even the community's acceptance of the corporation's existence (Bartkus et al., 2000; Ireland \& Hitt, 1992; Leuthesser \& Kohli, 1997).

However, a preliminary question still remains. When it sought to express the concept of purpose in corporate practice, why did the business literature adopt a term like mission, so fraught with meanings and which, as we will see, originated historically in the field of religion? In expressing the need for a clear definition of organizational goals, why was the term purpose not exclusively adopted (which, incidentally, is the term most associated with corporate mission in different conceptual definitions)? We claim that this is not a naive choice ${ }^{(1)}$. Frequently, the adoption of the term mission includes an implicit intention to manipulate the meaning of the organization's purpose, in order to legitimize these actions in contexts where religious values have a strong symbolic power. We assert that the answer to these questions lies precisely in the theological significance which the term mission still carries. This significance, as will be discussed, comes from the etymological origin of the term and still clings to it, despite the historical merging of new meanings. This kind of heritage of meaning - identified by Koselleck (2002) as the historical referentiality of the concepts - explains the actual usage of the phrase corporate mission statement, that is to say, the use of this communication resource as a tool which provides corporations with an appropriate message according to its socially decodable meaning. The usefulness of this meaning is its power to build a compelling sense of purpose which is incorporated by the different audiences to which the statement is addressed. Because of this, the corporate mission can be used as a tool of organizational communicative distortion, as will be discussed below.

\section{Organizational Communication as Communicative Distortion}

Based on Habermas' work, Forester (1983) has proposed criteria for analysing organizational discourse as a systematically distorted communication process. Following the phenomenological idea that "organizations can be recognized as systematic structures of communicative interaction" (Forester, 1983, p. 240), the author describes organizational power structures and forms of communication as elements strongly influenced by the manipulation of the meanings attributed to organizational actions. According to this view, organizations are pressured to produce economic results and, in order to succeed, they frequently build discourses purposely oriented to the establishment of favourable social and political contexts. In this sense, Forester (1983, p. 242) explains that, "organizations produce results, to be sure, but they also, and more subtly, reproduce the beliefs, consent, trust, and attention of their members and those with whom they interact".

At this point, Habermas' (1985) Theory of Communicative Action helps to clarify this process of manipulation of meanings. According to him, a speaker can deliberately make use of three ontological dimensions - validity claims - which are observed in linguistic statements commonly used during communicative interactions. These are: (a) a truth claim, assumed when the communicative statement tells something about an objective and sensible reality; (b) a legitimacy claim, assumed when the communicative statement is normatively aligned with socially accepted values; and (c) a sincerity claim, assumed when the communicative statement refers to the speaker's intention or subjectivity in a way which reflects their interior state. Then, in the context of linguistically mediated social relationships, the communication which is systematically distorted occurs when the speaker deliberately induces a false idea through their claim or speech act. 
According to Forester (1983), in this way organizations produce communicative distortions, by, for example, manipulating members' or publics' beliefs through the omission of information or production of false data, or confound their audiences through the production of ambiguous speech, jargons or excessive quantity of information. Another communicative distortion used by organizations to manipulate various publics' trust is the use of false promises and symbolic decisions. In this way, they induce receptors' consent through some demagogic claim which looks as though it will produce results for the public benefit but which, instead, covers the actual private interests of the organization.

In this context - according to Habermas - organizational communication can be understood as a structured process conditioned by the manipulation of meaning. This is so because the interactions which take place inside modern organizations are conditioned by the modern rationalities of market and bureaucracy logics (Friedland \& Alford, 1991), which produce hierarchical, asymmetric and nonreciprocal relationships (Forester, 1983). Consequently, in order to gain support for their interests, actions and results, organizations make strategic use of systematic distorted communication as a persuasive mechanism. In this sense, the rhetoric observed in organizational discourse can be viewed as a communicative distortion mechanism deliberately used to persuade specific individuals or social groups. In other words, the rhetoric is a practice of cognitive legitimacy construction in that it is supported by culturally valid rules and values (Suddaby \& Greenwood, 2005) and is at the same time linguistically manipulated.

Considering the crisis of legitimacy faced by the founding institutions of modern capitalism (Habermas, 1989), this kind of distorted discursive construction of social consensus is associated at the societal level with the idea of organizational legitimacy. This phenomenon has been explored in organization studies by institutional theory (Friedland \& Alford, 1991; Suddaby \& Greenwood, 2005). From this point of view, the desired organizational legitimacy is located in higher-order societal institutions, which support modern social life and which include the logic of capitalist accumulation, the logic of the formal rationalization of the state and also the logic of religion.

In this context, considering the importance of rhetoric in constructing organizational legitimacy (Suddaby \& Greenwood, 2005), we suggest that the systematically distorted communication of organizations is firmly directed towards the construction of legitimacy in modernity. We are particularly interested in understanding how corporate mission statements are used as a systematically distorted way by which organizational communication seeks legitimacy for itself. Our central argument is supported by the fact that the corporate mission statement has etymological and historical roots in theology. From this point of view, the idea of corporate mission may carry Christian values, albeit strongly influenced by secular thinking.

In order to develop our thesis, we subsequently present a brief discussion of the relationship between theological and corporate conceptions of mission in the light of Reinhart Koselleck's Conceptual History framework. In doing so, we demonstrate how the meanings which precede the use of some words allow - but in some cases contaminate - the present understanding of its meaning. Then, in the next section, we consider the development and role of Christianity in the historical and cultural formation of modernity. In this section, we show the historical process by which the theological concept of mission was secularized. In this way we can follow and develop our argument about the way in which modern corporate mission statements are sometimes used as manipulative communicative tools which seek organizational legitimacy through the rhetorical inclusion of secularized Christian values. In doing so, a modern organization may project a sacred image before its publics, in spite of its selfish economic motives.

\section{Conceptual History's View of Religious and Corporate Concepts}

When the German historian Reinhart Koselleck developed the historiographical method called Conceptual History, his purpose was to understand the emergence of modernity. To this end, 
Koselleck proposed the study of fundamental concepts which helped to construct and transform social reality during the historical period which he calls Sattelzeit (1750-1850). He studied, for example, the transformation of meanings associated with terms originated by Aristotle - freedom, equality, democracy, history - when they became used for a political purpose, that is, when they were used to describe a modern utopian vision of the future. In Koselleck's theoretical framework, polysemic concepts such as these - which are synthetic theoretical abstractions from concrete phenomena reveal the emergence of distinct historical time periods and may inherit meanings previously associated with a specific term. For this reason, even though each discursive use of language is unique and always synchronous - one act here and now - it contains in itself a diachrony which lends (old) meaning to the concept.

Inspired by Heidegger's thinking, the Koselleck's Conceptual History assumes an existentialist perspective founded upon historicity and on the importance of future expectations as existential principles of human temporality. History, thus, is the result of interactions between the space of experience and the horizon of expectation. Koselleck develops these two terms to capture the temporal polarity between past and future as a framework for action in the present. From this theoretical perspective on history, the concept is the element in which human past experiences and future expectations are manifested in the same way as they are interpreted, understood and narrated in some specific social context. By studying the concepts, it is possible to capture transverse (or simultaneous) and longitudinal (or non-simultaneous) meanings associated with the terms used to describe socially and historically located human action.

Between the many implications of the use of Conceptual History in understanding social phenomena we want to highlight the assumption that the meanings which precede the use of some words always allow and sometimes contaminate the present understanding of the meaning. Thus, the semantic content of a concept lasts longer than its use in a specific situation. That is, each concept carries meanings acquired throughout time. In this sense, the semantic continuities and variations in the content related to a concept can support historic studies about the way in which different societies give meaning to their existence and interpret their expectations of the future.

On the basis of Conceptual History, we can better understand the mission concept. For example, we can recognize, even in recent history, several uses of this term in different fields of knowledge. Even as a term of wide and common use, the mission concept stands out in certain areas, such as the military and religious areas and also that of business, which concerns us. But the two main areas of theoretical debate about the mission concept are the religious and the managerial, considering that it was in these two fields of activity that theoretical systems were formed around this idea.

To define the genealogical sequence of the different concepts of mission, we can simply address the etymology of the term. The word comes from the Latin mitto, meaning send and its original meaning derives from the Judeo-Christian belief that God would send the Messiah, his Son. In this sense, it is interesting to note that the development of the term in the religious field supplied its commonsense content in societies based on a Christian culture.

In attempting to revalidate the mission concept as it moved from the religious world to the business world, we may recognize an expansion of its content and meanings. For Koselleck (1985), it is a common process for concepts to be challenged by social usage over time. Thus, the corporate mission concept takes on a more practical sense, as given by the phrase mission statement, which is understood by many scholars to mean some way of instigating the successful financial performance of a corporation (Williams, 2008). Furthermore, the adaptation of the concept from a theological one to the secular needs of business was an additional challenge for the users of the concept (managers, organization scholars, consultants, management students and teachers, etc.). As with the difficult task of incorporating the term in a new logical system, the challenge of linking the theological concept of mission to business literature lay in the almost utopian integration between capitalist interests of selfish nature and the unselfish concern for the greater collective welfare (Capaldi, 2005), lent by the theological meaning, which connotes the expression of the divine will or common good. But the increasing recognition of religion as a foundational element of social construction helps to elucidate 
the way in which religious principles and values are incorporated into the discourse of economic organizations.

\section{The Colonial Origin of the Christian Influence in American Societies}

Two sects with a Judeo-Christian origin played a fundamental role in the process of colonizing the New World, namely, Roman Catholicism and Protestantism. However, whilst Catholics were mainly motivated by the colonizing adventure as a means of expanding the Christian faith and giving support to European crowns (Benavides, 2001; Bosi, 1994), Protestants viewed the newly discovered lands as a chance to escape persecution in Europe as well as an opportunity to build up realms of religious freedom (Porterfield \& Corrigan, 2010). Nevertheless, despite their different motivations, both Catholicism and Protestantism undeniably helped to shape the social climate for those who lived in the Americas.

In British colonies, there was a strong Protestant influence in the colonization process. In this sense, Max Weber's thesis (2001) regarding the relationship between the Protestant ethic and capitalist economic behaviour helps to prove how religion gave a new spiritual sense and a positive moral significance to earthly life. In these terms, Weber thesis clarifies how Protestantism established a close relationship between secular earthly work and eternal redemption. More importantly, he notes how this rationale offered a basis for the development of capitalist economic life as it was led in the British colonies:

But at least one thing was unquestionably new [in the central dogma of all Protestant denominations]: the valuation of the fulfilment of duty in worldly affairs as the highest form which the moral activity of the individual could assume.... The only way of living acceptably to God was ... through the fulfilment of the obligations imposed upon the individual by his position in the world. That was his calling. (Weber, 2001, p. 80).

In the Portuguese and Spanish colonies, the relationship between religion and the formation of society was marked by a close relationship between the Catholic Church and the State (Benavides, 2001; Skidmore, 1999): "During the colonization of Latin America, therefore, Christianity fulfilled the double role traditionally accomplished by religion: that of validating a social order, beginning with the justification of the conquest itself, while also providing the justification for judging that same order" (Benavides, 2001, p. 1764). Partners in the colonizing venture, priests and settlers, whilst representative of the European crowns, were mutually supportive in the process of dominating native peoples and, later, African slaves (Fausto, 2001). By establishing new standards of social conduct based on the customs and traditions of the colonizers, Catholicism brought to the colonies the principles of Christian faith and helped to undermine the importance of local religious practices. Nevertheless, the influence of the Catholic Church was not limited to religious practice and thinking. For instance, the services provided by the Church to the Crown were usually rewarded with large tracts of land. This enabled it to build monasteries and churches, which ultimately offered the space for formal education and the establishment of institutional foundations in the colonies (future independent countries) (Perry, 2011; Roberts, 1993). The Jesuit mission is a typical example of the way in which Catholicism was institutionalized in the colonies and in due course contributed to the civilizing efforts of the colonizer (Bosi, 1994). Hence, unlike some itinerant missionary initiatives, which found little success, Jesuit missions were able to turn their settlements into centres of agricultural and industrial production which offered native people housing, work, food, protection and medical care (Spielvogel, 2011).

Some of the fundamental principles of Christian theology directly influenced the formation of American societies' cultures. Among them, we can highlight the eschatological expectation of final Redemption, which includes an appreciation of the future as a time of peace, prosperity, happiness and brotherhood. According to the Christian doctrine of the application of Redemption (Grudem, 2008), 
every man has sinned and is separated from God. However, through the vicarious sacrifice of Christ, God's grace gives to all humanity the chance to repent from sin, conversion, justification and baptism. In this way, any man or woman can gain righteous legal standing before God and, as a result of a continuous process of perseverance and personal sanctification, will be glorified and forever united with Him. The Christian doctrine of the Future describes the series of events which will finally lead to the emergence of the new heavens and new earth. In respect to these places, Grudem (2008, p. 1163) says: "The new creation will be a place of great beauty and abundance and joy in the presence of God (Rev 21:1-27; Rev 22:5)". In this view, the future is the ultimate establishment of a perfect world, where poverty, injustice and suffering no longer exist. By this, Christian thought offers comforting answers for life and death. Moreover, the eschatological idea of a future reality free from suffering and injustice form the basis for the argument of a necessary and urgent reconnection between God and his creation. Ultimately, access to such an ideal future (heaven), implies repentance and moral transformation. Through this prospect, religion is seen as capable of transforming individuals and society as a whole.

This fundamental principle of Christian theology - i.e. the happy and peaceful future promised to those who have accepted Jesus vicarious sacrifice - motivated the religious missionary initiatives during colonization, especially because they considered the natives as uncivilized, poor, needy and hopeless people. Missionaries were believed to be sent - by the Church or by God himself - as God's representatives to announce the Truth. In this way, the missionaries became co-builders of this New World and helped to influence the process of cultural colonization.

\section{The historical trajectory of the theological concept of mission}

Throughout the history of Christianity, as pointed out by Bosch (1991), paradigm shifts in the theology of mission can be identified which help us to understand the current meanings attributed to the term. By examining twenty centuries of Christian history, the history of the concept can be reconstructed to provide a historical basis for the present discussion.

As already noted, the word mission comes from the Latin mitto, meaning I send. Originally the term was used to describe the sending of the Son of God, Jesus, to mankind and later the sending of the Holy Spirit to dwell among the Christians. The expectation of Jesus' return brought with it the idea that the kingdom of God would be established on earth:

The classical doctrine on the missio Dei as God the Father sending the Son, and God the Father and the Son sending the Spirit was expanded to include yet another 'movement': The Father, Son and the Holy Spirit sending the church into the world (Bosch, 1991, p. 390).

The mission became the essential task of every Christian, according to the directions of the Gospels of the New Testament: "And he [Jesus] said unto them, Go ye into all the world, and preach the gospel to every creature" (Mark 16:15 King James Version).

In the Patristic period, Christianity became increasingly differentiated from Judaism and other religions of the time. A Church more concerned with its own establishment as a universal religion of humanity arises. The concept of mission changed to be related to the idea of spreading the Christian culture, and not only preaching the gospel of salvation that frees the soul from everlasting destruction, according to the Pauline sense.

In medieval times, groups opposed to a Church increasingly linked to the State and, therefore, considered mundane, began to manifest themselves and take extremist positions. Yet in the Middle Ages, there was a movement in favour of waging holy wars, crusades planned to subdue nonChristians and lead them to righteousness. The mission then started to identify itself with war - of a simultaneously military-imperialist and religious purpose - acceptable for the benefit of the Catholic Church. The so-called Crusades became common practices in an attempt to Christianize the known world. And when they came to unknown continents and peoples, European Christians saw themselves facing a new challenge: In addition to spreading the Christian faith, they felt responsible for civilizing 
the newly colonized Africa, Asia and America: "Colonialism and mission, as a matter of course, were interdependent, the right to have carried colonies with it the duty to Christianize the colonized" (Bosch, 1991, p. 227).

In this context, the mission became the task of sending ecclesiastical agents - who were called missionaries - to distant colonies. Previously, the activity of proclaiming the Gospel was called propagation of the faith, preaching the gospel, expansion of the Church, Church establishment, among other terms. The new word mission, therefore, is directly linked to the colonial period and the idea that there was a commission to be accomplished by the Church representatives who were sent to the colonies. As a result, in the period of the European expansion, the word mission comes to mean activity of spreading the Western faith to the rest of the world.

With the Protestant Reformation in the sixteenth century, the Church's role in the salvation of sinners was revised, mainly attributable to the return to the biblical idea that justification comes by faith and not by works or by baptism. Salvation became an individual choice, in which an individual chooses to accept the vicarious sacrifice of Christ. The mission, preaching and teaching of the Gospel to non-Christians, becomes an individual task of every Christian, and is no longer institutional.

As of the seventeenth century, Enlightenment ideas began to influence Christian religions, especially Protestantism. Increasingly, Westerners started to take on a way of thinking strongly influenced by science and contrary to the supremacy of God, of the Church and of the Crown. The autonomy of human reason became progressively more valued and a growing opposition between science and faith started to emerge. The radical anthropocentrism of the modern era promoted hostility to the Christian faith. The effects of the Enlightenment on Christian missionary endeavours are evident, particularly in the emergence of different interpretations for the millennium of the reign of Christ, in accordance with the Bible proposal. While the pre-millennial people believed that the millennium would begin only after the return of Christ, the post-millennial people believed that the millennium had already begun and it was up to Christians to promote the advancement of society. These two motivations - preaching of the gospel and fighting against degrading social conditions impelled the creation of missionary movements also anxious to struggle against the rationalism encouraged by the Enlightenment.

\section{The secularization of the theological mission concept}

Between the late nineteenth and early twentieth century, U.S. missions strongly reflected over the two movements - pre- and post-millennial - the latter distinguished by a strong correspondence between 'expansion of the kingdom of God' and 'expansion of the American middle-class lifestyle'. Among the core values and principles recognized in the American lifestyle are: material prosperity, universal peace, happiness, progress in the arts, efficiency, capitalism: "In this vision the reign of God had been transformed into the extension of American institutions to all the world" (Bosch, 2011, p. $315)$. With time, a sort of missionary philanthropy was founded, concerned with saving the poor from countries considered economic and culturally underdeveloped. For the most part, Western missionary agencies were complicit in the project to civilize according to Western values. It was believed therefore that uncivilized people depended on aid from Western Christians. Mission, piety, patriotism and politics mingled in missionary speech and actions. Over time, concern for the salvation of individuals evolved into a concern for society as a whole.

In the second half of the twentieth century, the phenomenon of 'social Christianity' or 'Social Gospel' continued to express the entrepreneurial power of the American and English missionary societies. These societies were acting according to principles very similar to those used in the business world. Thus, there was a concern for establishing goals and well defined guidelines. Furthermore, it was common to compare missionaries with soldiers and to develop plans and missionary strategies. The 'army of God' should move forward and conquer the world. The emerging paradigm of mission noticeable during the twentieth century - reflects the changes that occurred in the confidence placed in science and the scientific knowledge. In this context, the Christian mission, surviving rationalists' 
attacks, resurfaces as an alternative that gives meaning to life and offers an anti-nihilist eschatological perspective.

Currently, the concept of mission assumes new shapes, marked by the emerging post-modern paradigm. And while these contours are still barely outlined, we can see an increasing involvement of Christians in the world, through the fulfilment of the mission in the spiritual, social, economic and political areas.

In summary, the theological concept of mission has acquired new meanings as a result of many historical contingencies. Although it maintained its original meaning of "send", the contemporary Christian mission has incorporated new attributes related to other areas of human and social life besides the spiritual one. In doing so, the concept has amplified its semantic coverage and has included secular concerns related to social, economic and political issues: "The move from evangelism to social concern had, as its natural corollary, a shift of interest from individual to society" (Bosch, 2011, p. 323). In this sense, the secularization of the concept points to the Christian mission as an earthly achievement to be held through charity and spiritual or material earthly redemption. In other words, the earthly redemption is a search for the common good inasmuch as it reflects the possibility and pretention of happiness for all humanity. However, to the contrary of its original meaning, the modern idea of happiness has been increasingly associated with the (North) American lifestyle, which is directly related to capitalism.

\section{Corporate Mission as Communicative Distortion: the Discursive Manipulation of a Concept Inherited from Christian Theology}

As noted above, corporate mission statements may be used in order to help build an image aligned with social expectations of things done by for-profit organizations. At the same time, we can look at such statements as illustrations of communicative distortion which set out to create a false consciousness (Forester, 1983; Habermas, 1985). From this point of view, a for-profit organization can deliberately use the potential of its corporate mission statement as a communicative tool for minimizing the negative impact of its actions (Forester, 1983). In other words, when organizational actions and decisions are at the same time profit-oriented and potentially damaging to some of the stakeholders, the corporate mission statement is likely to be used to deviate attention.

In this sense, we can understand the corporate mission statement as a desired self-image (according to Pearce \& David, 1987) which is not necessarily sought. Maybe the company does not act upon it because it realizes that seeking this kind of non-profit purpose can lessen its profitability. For example, in motivating consumers' conscious use of credit, a bank can harm its interest income. In other words, the contradiction between values and principles which appears between corporate mission statements and actual core business activities can in many cases be viewed as a rhetorical discursive tool. In this sense, in presenting an image related to socially legitimate values and principles, a corporation may be seeking to build confidence among its target publics. This is why Bart (1997) evaluates the adequacy of a corporate mission statement by its capacity to inspire the organization's stakeholders, an adequacy which does not need to involve any sincere intention on the part of the organization (using Habermas' framework language). For example, Leuthesser and Kohli (1997) studied corporate mission statements of 393 out of 1000 corporations listed by Business Week and concluded that there were many vague statements about the way in which the good intentions for consumers and employees would actually be implemented. This is a case with Forester's (1983) sincerity validity claim distortion, but it can still reflect a manipulation of meaning by setting socially legitimate values within a for-profit corporate mission statement. In this way, we can identify the kind of discursive manipulation which has been used to equip corporate mission statements with Christian theological values and principles. In this way, for-profit corporations impregnate their desired public images with meanings inherited by the historical and theological attributes related to the concept of mission. So, based on the Christian values and principles which helped constitute Western societies, 
the corporate mission statement becomes an important discursive tool in creating meaning and social consent within these societies.

In order to advance our central argument, we highlight, in the following topics, three Christian principles which may underlie the corporate discursive use of mission statements: (a) the idea of redemption to be accomplished through building a better world, incorporated from a secularized form of Christian mission; (b) the idea of common good implicit in the universalistic purpose of Christian theological mission; and (c) the idea of the sacred and sacralization as a criterion of a mission's legitimacy. In presenting each of these principles, we have added commentaries on how organizations include them into their corporate mission statement. For illustration, we cite some actual examples of corporate mission statements. Those presented below have been chosen because: (a) they are actual for-profit corporate mission statements; and (b) they are put forward by economically successful corporations. These two further criteria are important because for-profit organizations have emerged under the monopolistic logic of capitalism (Braverman, 1998). In this sense, their final purpose is to accumulate capital through profit maximization. This leaves wide open the contradiction between such organizations' promises to pursue goals which may potentially harm their profits or which cannot be realistically implemented through their usual activities. We have purposely chosen corporate mission statements which demonstrate a discursive use of the three Christian principles we have found to reflect the theological heritage of the mission concept. In doing so, we are only providing an illustration of our arguments, because it is not our intent to generalize the results of this study.

\section{Corporate mission as redemption}

The theological concept of mission implies an alliance between the one who sends and those who receive/accept (Bosch, 1991), which is committed to creating a better world. While the medieval idea of a better world was completely spiritual and something to emerge only after the Final Judgment (Koselleck, 1985), in the modern secularized idea of Christian mission this better world is built upon the earth, through the happiness secured for everyday life (Ashforth \& Vaidyanath, 2002; Capaldi, 2005; Porterfield \& Corrigan, 2010).

To say this, as we noted above, is to claim that eternal redemption is an important semantic property of the concept of mission. However, as observed by Weber (2001) through his idea of vocation, the secularized concept of mission connects salvation with economic success. In this secularized sense of Christian mission, earthly redemption is achieved through the economic prosperity of those who were chosen by God to enjoy eternal salvation and bliss. In the struggle established during the Cold War and embraced by secularized movements in the USA (Bosch, 1991), earthly redemption was seen as possible through the adoption of an American model of life and prosperity. From this standpoint, earthly redemption is obtained through material consumption and full employment, according to the post-war expansion of the socioeconomic model of development followed by the U.S. middle class (Harvey, 1990).

In the formulation of many corporate mission statements, the principle of redemption is frequently emphasized. In many cases, we can glimpse terms and textual expressions denoting the idea that corporations will secure the establishment of a better, more prosperous and happier world on earth. In Global Gillette's mission statement, for example, some terms - in bold in the quotation below - contribute to fill in the sense of a better world:

We will provide branded products and services of superior quality and value that improve the lives of the world's consumers. As a result, consumers will reward us with leadership sales, profit, and value creation, allowing our people, our shareholders, and the communities in which we live and work to prosper (Procter \& Gamble, 2003, p. 2).

In this example, even taking into account that the corporate economic interest is being portrayed by the use of words such as profit, value creation and leadership sales, the bolded expressions stress an idea of reciprocity between the We (Global Gillette) and the consumers which implies an alliance deliberately built in order to create prosperity in the community. Actually, according to the secularized 
Christian idea of prosperity as economic success, the inclusion of an economic purpose is not contradictory. As we can see in many cases, one alliance made for the purpose of defending capitalist interests is identified as a way to implement the better world proposed by Christian theology.

Second, a corporate mission statement is a tool for communicating the potential contribution of the organization in building a utopian future which significantly improves on the present. The idea of progress and improvement is evident in the mission statement of The Dow Chemical Company: "To constantly improve what is essential to human progress by mastering science and technology" (The Dow Chemical Company, 1995-2013). Here, we observe the direct mention of human progress as an organizational goal.

In summary, redemption as it is promoted by some corporations through their corporate mission statements implies the idea that their activities are essential to building a better world for all humanity; that the earthly heaven promised in Christian theology will be established only through the help of corporations and their products and services. This connection between their actual purpose of making profit and of building a better world leads to a false consciousness about some corporations' intentions with respect to the common good, as we present in the next section.

\section{Corporate mission as common good}

In association with the redemption idea of mission emerges a false idea of corporate benevolence. This intended image of kindness is a communicative distortion of the validity claim of sincerity (Forester, 1983), which provides the sense of compassion and mercy socially expected in Western societies. Thus, according to its secularized theological semantics, the concept of mission implies a behaviour characterized by the search for a common good through actions of justice, philanthropy and charity. Among corporations, these principles are expressed not only by the rhetorical use of such terms, but through (sometimes assumed) engagement in social causes. For instance, it is particularly common to observe interest in environmental causes from corporations whose central activity is widely known to be environmentally damaging. This is the case of the Newmont Mining Corp's corporate mission statement, which acts as a mask to the bad image of extractive activities such as mining: "Newmont and its affiliates (Newmont) intend to set standards of excellence with regard to environmental matters". (Newmont Mining Corporation, 2011)

One rhetorical device used by companies to create this sense of relating to a common good is a generic reference to collectivities which address the stated purpose, such as community, neighbour, humanity, human beings, men, woman or children. As pointed out above, in the secularized theological concept of mission, the divine will is incarnated in humanity itself (Bosch, 1991). In this sense, the organizational purpose becomes a collective one, in that it benefits humanity. This claim, which is found in many corporate mission statements, can be observed in several forms. As we have seen, sometimes it is possible to find humanity, human beings or some other collectivity directly mentioned, as we see in statement mission of the Dow Chemical Company, with its focus on human progress. It is also customary to refer to human groups in general, as they occur in such terms as family, women, children, or society: for example, "to give unlimited opportunity to women" - Mary Kay Cosmetics (Center for Business Planning, 2011), or "to invent beauty and meet the aspirations of millions of women and men" (L'Oréal, 2010, p. 3). The problem with this type of meaning construction may be found in the very origins of the corporation. That is, corporations are created mainly to serve private and not humanitarian interests. This is clear when a corporation states its focus on shareholder return.

At this time, there is a major conflict of between private and collective interests, which the critical literature of management practices observes with significant skepticism. For example, Doane and Abasta-Vilaplana (2005) point this out when they evaluate the corporate social responsibility concept. Moreover, this collectivist perspective leads to the erroneous belief that an organization's goals transcend purely economic interests. In this regard, many mission statements are written to suggest benefits which go beyond economic results and acquire other meanings. For example, 
Starbuck's mission statement maintains that the organization seeks "To inspire and nurture the human spirit - one person, one cup and one neighborhood at a time" (Starbucks, 2010). In other words, this mission suggests that the act of consuming the products of this organization leads to a kind of inspirational and spiritual nutrition.

Finally, even if we consider that there is an alignment between the principles of capitalism and secularized Christian missiology, mention of economic interests is frequently omitted in order to divert the attention of the target public from the actual profit-oriented focus of the organization.

\section{Corporate mission and the organizational sacralization}

The third principle we want to highlight here - as a signal of the theological heritage of the concept of mission - is the idea of the sacred. To be sacred means to be connected with God and it is a property of things which should be separated or detached (Turner, 2010). In liturgical terms, this detachment means being put on a pedestal. Moreover, the sacred is generally shown in a dogmatic way, in which symbolizes the connection with a divine will. In this sense, the sacred is not completely understandable. So, if a mission can be seen to represent God's will, it is in essence sacred. Consequently, being sacred, the mission is unquestionable and must be unconditionally fulfilled. In the same way, because of its inherited conceptual meaning, any corporate mission is supposedly sacred and worthy of respect.

Having a corporate mission takes on an imperative sense, in that the sacred connotation of the theological concept pervades the spaces of experience and horizons of expectation (Koselleck, 1985), down to the contemporary use of the term. Even considering that the sacred, as opposed to the secular dimension of organizations, is established in the present age - most of all given the assumptions of capitalism (Capaldi, 2005) - the enshrinement of values and ideals finds room in social space. As Harrison, Ashforth and Corley (2009, pp. 229-230) assert: "What makes organizations approximate to sacralization is the trajectory toward the sacred - the espousal of the existence of processes that provide the raw materials for individuals to begin to seek more transcendental experiences within the purview of the organization".

In this view, the development of the corporate mission statement is one of the processes of constructing the sacred, for it provides individuals with a transcendental (or non worldly) meaning for their actions. More than this, the sacralization built through the organization discourse also facilitates the social legitimacy particularly desired by for-profit corporations. This is why, as Williams (2008) argues, corporate mission statements contain a clear expression of goodwill for certain audiences. By expressing this, these organizations aim to obtain the social legitimacy necessary to justify their existence, despite the potentially damaging effects that their actions might engender.

We can conclude by this that corporate mission statements are used as a means by which some corporations may internalize the sacred. And, moreover, we can reinforce our central thesis that organizations discursively manipulate the Christian concept of mission to gain legitimacy through the pillars of the religious culture. So, contrary to the widespread idea that modernization and secularization are intrinsically connected with the abandonment of the sacred (Davie, 2010), what is historically and contemporaneously observed is the sustained life of religious values and principles in a process which we may call sacralization (Davie, 2010; Harrison et al., 2009). As an example, we may cite the continuous importance of family (Friedland \& Alford, 1991) as a fundamental institution of contemporary capitalist societies. In Christian theology the family is sacralized, as we can observe in one of the biblical Ten Commandments, "Honour your father and your mother, so that your days may be long in the land the Lord your God is giving you" (Exodus 20:12 NRSV). At the same time, family manifests itself as a secularized institution which is regulated through economic and legal relationships. And, more recently, family has been manifested as a sacred value in some corporative discourses. We can see some examples, as in the corporate mission statements of Ford ("we are a global family" - Kotelnikov, 2010) or Conseco, Inc.' ("[we are meant] to be a premier provider of insurance products to America's working families and seniors" - CNO Financial Group, 2004). In both 
cases, the mention of the term family appears to be intentionally linked to the corporation's desired association with the sacredness of family in religious terms. Similarly, other secularized Christian values such as material prosperity, universal peace and happiness have been used in corporate mission statements.

As a communicative distortion, the corporate mission statement can be considered, ultimately, as a pseudo-sacred discourse. This means that this kind of discourse makes the actions of corporations look as though they are sacred, inviolable and unquestionable (Demerath et al., 1998). According to Harrison et al. (2009, p. 227):

what the concept of 'sacred' adds to the management literature is the idea that core organizational elements such as identity (who we are), culture and ideology (what we value and believe), and strategy (what goals we pursue and how) may become inviolable, affecting how these elements are conceived and enacted and how individuals respond to perceived violations.

Yet, if one of the main uses of the corporate mission statement is to indicate the organization's raison d'être (Ireland \& Hitt, 1992), having one of its organizational purposes considered sacred leads to the widespread belief that the organization itself is sacred. This is why, for Ashforth and Vaidyanath (2002), in contemporary societies where the sacred has been secularized - that is, translated into issues of worldly importance - when corporations assume some sacred values as their own, such as justice, welfare, quality of life, honesty, etc., they are thought to assume a social status equivalent to that of religious institutions.

As already noted, the sacred connotation of corporate mission is built up in the way that the mission statement is written, which almost always puts into the limelight the socially acceptable and noble values which, to put it mildly, conflict with the pursuit of those private interests on which forprofit organizations are built. This selfless vision on the part of for-profit organizations is viewed as a strong element in management's discourse, as demonstrated, for example, by the idea of corporate social responsibility (Doane \& Abasta-Vilaplana, 2005).

It should be also remembered that for-profit companies of the late nineteenth and early twentieth century - the companies from the U.S.A. in particular - were born into a theologically Protestant environment where people believed in saving the world through an extension of Western techniques and culture (Bosch, 1991; Weber, 2001). Among the first American businessmen there was a belief in the success of their economic enterprise as a way of establishing the kingdom of God upon earth. From this belief derives the idea that it was possible to make social progress through economic progress, which would justify the capitalist venture as a demonstration of social goodwill. This value is strengthened in common-sense minds because it is a sacralization of business achievement, which has been culturally crystallizing until the present day.

In modern culture, the vision of entrepreneurship as a sacred activity is reinforced by other values which also become sacred, insofar as they are justified by the vision of humanity and the promotion of collective welfare. For example, this has happened with the modern concept of progress, a concept which reinforces the values of the West and has conditioned the recent cultural colonization of the East and the southern hemisphere (Harvey, 1990). In modern organizations, these values adopt the function of accounting for managerial acts as socially legitimate and translatable within the vision of instrumental rationality (Forester, 1983; Ramos, 1981). Therefore, being rational, the formal organization - and thus its management - reflect the pursuit of human progress. The corporation, being the expression of progress and rationality, therefore becomes a humanitarian project; that is to say, a project justified by being reflected in the welfare of humanity. This perception of for-profit organizations overlooks the hard reconciliation of private and collective substantive interests in a market-based society (Ramos, 1981). At the same time it is seen as an altruistic and powerful discourse for minimizing social criticism of the expansion of corporate economic interests (Doane \& Abasta-Vilaplana, 2005). Hence, the formulation of a corporate mission is inevitably manipulative, since it is rhetorically set up as a social and substantive duty. 


\section{Conclusion}

In this paper we have taken a critical stance towards the discursive use of the mission concept by the business world and its communicative implications. In so doing, we follow the view of organizations taken by Theory of Communicative Action (Forester, 1983), which reveals the corporate mission statement as one of the boldest communicative distortions used by a corporation for the purpose of manipulating social perceptions and diverting stakeholders' attention from potentially damaging actions.

Through our argumentation, we pointed out that use of mission concept within the corporate world was made for a discursive purpose, with a strategic intent of appropriating its secularized religious connotations. Our thesis, in analyzing the history of the theology of Christian mission is that recent years have registered a diachronic persistence in the human experiences related to the term. This is seen from the unremitting concern with duty towards God and one's neighbour. The corporate mission, then, is undertaken in a similar way to a religious mission; i.e., on behalf of God and at the same time having to serve as a link between God, the missionary (the role played by the corporation) and other human beings. This double dimension - spiritual and material - is manifested in actions of justice, philanthropy and charity and is supposed to be associated with organizational identity and action.

As a result, the mission statement, as a communicative tool, represents a powerful mechanism for performing systematic communicative distortion (Forester, 1983), since in invoking the sacred, it influences the imagination. Moreover, the theological heritage carried by the term and the rhetorical structure of the formulations of some corporate mission statements reflect a way of constructing organizational sacralization (Harrison et al., 2009). Its aim is to convince people that they must adopt the organizational mission as their own, an identification process which promotes engagement and subservience (Alvesson \& Willmott, 2002). It is no coincidence that the development of 'mission statement' is viewed as a primary motivation to higher performance (Leuthesser \& Kohli, 1997) and has been widely adopted by managers. It allows the firm to build a powerful self-image, based on the sacralization of corporate values. This highlights the fact that the organizational world and also the secular culture, broadly understood, are still heavily influenced by traditional symbolic forms, in particular those which have been shaped throughout centuries of Christianity (Ashforth \& Vaidyanath, 2002; Capaldi, 2005).

This study sought to contribute to organizational studies by analysing the secularization of a theological concept in the organizational context and the sacralization of organizational activities in Modernity. The theological foundations of our thinking on organizations were stressed through the critique of the manipulated discursive use of the corporate mission statement analyzed in its relation to the etymological and historical concept of mission as it was formulated and processed in the context of Christian ethics. In doing so, following Forester's (1983) critical framework of organizational activities, we have aimed to point out the way in which this kind of sacralization may stop the target public from thinking about organizations' actual profit-oriented foci and potentially damaging activities (for example, in social and environmental matters). As a result, a false consciousness about some organizational contradictions may induce its public - consumers, employees, society - to adopt a non critical posture toward a corporation.

We suggested that the concept of corporate mission is meant to carry religious values which are revealed through the discursive use of rhetorical elements in the formulation of these instruments of corporate communication. That is, the historically constructed concept of theological mission may influence the discursive construction and use of corporate mission statements. Thus, the corporate mission statement contributes to painting a potentially distorted corporate image which expresses the supposed sacredness of organizational actions. The desire of Western society to be credited with religious values becomes the substrate for the effectiveness of this important mechanism of 
communicative management. And, as they agree with the values invoked, stakeholders are encouraged to form an alliance of reciprocity with the organization, just as in the context of religious missions.

What we try to emphasize here is the fact that the use of the term mission referring to the purpose statement is crucial for explaining the potential of this communicative tool. As noted above, the mission with which it is credited reflects redemption and interest in the common good, for it is justified as a sacred project and implies a manner of action typical of Christians in their intention of establishing the kingdom of God. In other words, when we use the word mission, the missionary meaning of a project comes forward to justify it as a divine plan, or even as a project for the good of humanity. Therefore, in this sense, a corporate mission should be accomplished, and, for this reason, must be accepted and socially legitimized.

\section{Note}

\footnotetext{
${ }^{1}$ As one of the reviewers astutely commented, the semantics related to the general mission concept and its connection with corporate use of the concept could be characterized under various semantic frameworks. So, even though we choose one interpretation, we do not expect it to be the only possible one, merely one of them.
}

\section{References}

Alvesson, M., \& Willmott, H. (2002). Identity regulation as organizational control: producing the appropriate individual. Journal of Management Studies, 39(5), 619-644. doi: 10.1111/14676486.00305

Ashforth, B. E., \& Vaidyanath, D. (2002). Work organizations as secular religions. Journal of Management Inquiry, 11(4), 359-370. doi: 10.1177/1056492602238843

Bart, C. K. (1997). Sex, lies and mission statements. Business Horizons, 40(6), 9-18. doi: $10.1016 / \mathrm{S} 0007-6813(97) 90062-8$

Bartkus, B., Glassman, M., \& McAfee, R. B. (2000). Mission statements: are they smoke and mirrors? Business Horizons, 43(6), 23-29. doi: 10.1016/S0007-6813(00)80018-X

Benavides, G. (2001). Christianity in central and south america. In N. J. Smelser \& P. B. Baltes (Eds.), International encyclopedia of the social \& behavioral sciences (pp. 1764-1767). Oxford: Elsevier.

Benefiel, M. (2003). Irreconcilable foes? The discourse of spirituality and the discourse of organizational science. Organization, 10(2), 383-391. doi: 10.1177/1350508403010002012

Bosch, D. J. (1991). Transforming mission: paradigm shifts in the theology of mission. New York: Orbis Books.

Bosch, D. J. (2011). Transforming mission: paradigm shifts in theology of mission (American Society of Missiology Series, n.16). New York: Orbis Books.

Bosi, A. (1994). Dialética da colonização. São Paulo: Companhia das Letras.

Braverman, H. (1998). Labor and monopoly capital (25th ed.). New York: Monthly Review Press. 
Bruce, S. (2010). Secularization. In B. S. Turner (Ed.). The new blackwell companion to the sociology of religion (Chap. 5, pp. 125-140). Chichester: John Wiley \& Sons Ltd.

Capaldi, N. (2005). Business and religion: the clash of civilizations? Salem, MA: M and M Scrivener Press.

Center for Business Planning. (2011). Mission statement. Retrieved from http://www.businessplans.org/mission.html

CNO Financial Group. (2004). Press releases: conseco reports third quarter results. Retrieved from http://cno.mediaroom.com/index.php?s=43\&item=18

Davie, G. (2010). Resacralization. In B. S. Turner (Ed.), The new blackwell companion to the sociology of religion (Chap. 7, pp. 160-178). Chichester: John Wiley \& Sons Ltd.

Demerath, N. J. III, Hall, P. D., Schmitt, T., \& Williams, R. H. (Eds.). (1998). Sacred companies: organizational aspects of religion and religious aspects of organizations. New York: Oxford University Press.

Doane, D., \& Abasta-Vilaplana, N. (2005). The myth of CSR. Stanford Social Innovation Review, $3(3), 22-29$.

Fausto, B. (2001). A concise History of Brazil. Cambridge: Cambridge University Press.

Forester, J. (1983). Critical theory and organizational analysis. In G. Morgan (Ed.), Beyond methods: strategies for social research (Chap. 15, pp. 234-246). Beverly Hills: Sage.

Friedland, R., \& Alford, R. R. (1991). Bringing society back in: symbols, practices and institutional contradictions. In W. W. Powell \&. P. J. DiMaggio (Eds.), The new institutionalism in organizational analysis (pp. 232-263). Chicago: University of Chicago Press.

Grudem, W. (2008). Systematic theology: an introduction to biblical doctrine. Leicester: Inter-Varsity Press. Michigan: Zondervan Publiching House.

Habermas, J. (1985). Theory of communicative action, Volume 1. Reason and the rationalization of society. Boston, MA: Beacon Press.

Habermas, J. (1989). Theory of communicative action, Volume 2. Lifeworld and systems: a critique. Boston, MA: Beacon Press.

Harrison, S. H., Ashforth, B. E., \& Corley, K. G. (2009). Organizational sacralization and sacrilege. Research in Organizational Behaviour, 29, 225-254. doi: 10.1016/j.riob.2009.06.002

Harvey, D. (1990). The condition of post modernity: an enquiry into the origins of cultural change. Oxford: Blackwell.

Ireland, D., \& Hitt, M. A. (1992). Mission statements: importance, challenge and recommendations for development. Business Horizons, 35(3), 34-42. doi: 10.1016/0007-6813(92)90067-J

Koselleck, R. (1985). Future past: on the semantics of historical time. Cambridge /Londres: The MIT Press.

Koselleck, R. (2002). The practice of conceptual history. Stanford: Stanford University Press.

Kotelnikov, V. (2010). Case study: Ford Motor Company: sustainable growth strategies. Retrieved from http://www.1000ventures.com/business_guide/cs_sg_ford.html

Leuthesser, L., \& Kohli, C. (1997). Corporate identity: the role of mission statements. Business Horizons, 40(3), 59-66. doi: 10.1016/S0007-6813(97)90053-7 
L'Oréal. (2010). L'Oréal Annual Report 2010. Retrieved from http://www.lorealfinance.com/_docs/us/2010-annual-report/LOREAL-2010-AR-volume1DEF.pdf

Mintzberg, H. (1994). The rise and fall of strategic planning. New York: The Free Press.

Newmont Mining Corporation. (2011). Beyond the mine: the journey towards sustainability. Retrieved from http://www.beyondthemine.com/2011/managing_sustainably/policies/environmental_policy

Pearce, J. A., II, \& David, F. (1987). Corporate mission statements: the bottom line. Academy of Management Executive, 1(2), 109-116.

Perry, M. (2011). Western civilization: a brief history (7th ed). Boston: Wadsworth, Cengage Learning.

Phillips, N., \& Hardy, C. (Eds.). (2002). Discourse analysis: investigating processes of social construction. Thousand Oaks, CA: Sage.

Porterfield, A., \& Corrigan, J. (Eds.). (2010). Religion in American History. Chichester: Wiley Blackwell.

Procter \& Gamble. (2003). P\&G: Our purpose, values and principles. Retrieved from http://www.pg.com/translations/pvp_pdf/english_PVP.pdf

Ramos, A. G. (1981). The new science of organizations: reconceptualization of the wealth of nations. Toronto: University of Toronto Press.

Roberts, J. M. (1993). A short history of the world. New York: Oxford University Press.

Skidmore, T. E. (1999). Brazil: five centuries of change. Oxford: Oxford University Press.

Spielvogel, J. J. (2011). Western civilization: since 1300 (8th ed.). Boston: Cengage Learning.

Starbucks. (2010). Our starbucks mission statement. Retrieved from http://www.starbucks.com/aboutus/company-information/mission-statement

Suddaby, R., \& Greenwood, R. (2005). Rhetorical strategies of legitimacy. Administrative Science Quarterly, 50(1), 35-67. doi: 10.2189/asqu.2005.50.1.35

The Dow Chemical Company. (1995-2013). Social responsibility. Retrieved from http://www.dow.com/greaterchina/en/about/social.htm

Turner, B. S. (Ed.). (2010). The new Blackwell companion to the sociology of religion. Chichester: John Wiley \& Sons Ltd.

Weber, M. (2001). The protestant ethic and the spirit of capitalism. New York: Routledge.

Williams, L. S. (2008). The mission statement: a corporate reporting tool with a past, present and future. Journal of Business Communication, 45(2), 94-119. doi: 10.1177/0021943607313989 